\title{
Plant diversity of Petungkriyono Forest of Dieng Plateau, Central Java, Indonesia
}

\author{
IRMA DAMAYANTI ${ }^{1, \bullet}$, AZIS NURBAMBANG ${ }^{2}$, TRI RETNANINGSIH SOEPROBOWATI ${ }^{3}$ \\ ${ }^{1}$ Doctoral Program in Environmental Science, School of Graduates. Universitas Diponegoro Jl. Imam Bardjo No.5, Pleburan, Kota Semarang 50241, \\ Central Java, Indonesia. •email: irmadamayantinugraha@gmail.com, trsoeprobowati@live.undip.ac.id \\ ${ }^{2}$ Department of Fisheries, Faculty of Marine and Fisheries Sciences. Universitas Diponegoro. Jl. Prof. H. Soedarto. SH., Tembalang, Kota Semarang \\ 50275, Central Java, Indonesia \\ ${ }^{3}$ Department of Biology, Faculty of Mathematics and Natural Sciences. Universitas Diponegoro. Jl. Prof. Soedarto. KecamatanTembalang, Kota \\ Semarang, 50275, Central Java, Indonesia
}

Manuscript received: 20 February 2021. Revision accepted: 28 July 2021

\begin{abstract}
Damayanti I, Nurbambang A, Soeprobowati TR. 2021. Plant diversity of Petungkriyono Forest of Dieng Plateau, Central Java, Indonesia. Biodiversitas 22: 3497-3507. Petungkriyono is one of the remaining forests considered as the key biodiversity site in Central Java, Indonesia. The study aimed to analyze the composition, structure, and diversity of flora. The research used 60 circular plots with 0.04 hectares on five sites: Tlogopakis, Kasimpar, Yosorejo, Kayupuring, and Tlogohendro. The result indicated that the forest was dominated by $54.6 \%$ mixed forests, $29.1 \%$ pine forests, $10.7 \%$ puspa forests, and $5.6 \%$ unproductive areas. A total of 979 individuals belong to 108 species, among 88 genera and 43 families. The dominant family was Moraceae (32.6\%) and has 10 species of Ficus spp as a key pioneer in a dry habitat. According to the Red List, the International Union for Conservation of Nature (IUCN), there were 4 species categories of endangered species (EN), 11 species as vulnerable category (VU), 46 species as least concern (LC), and 45 species not evaluated (NE). The horizontal and vertical structure of trees was dominated by $10-20 \mathrm{~cm}$ diameter classes and $82 \%$ at a medium level of the Shannon-Weiner index ( $\left.\mathrm{H}^{\prime}\right)$. The conclusion is that plant diversity plays a significant role to maintain ecosystem stability, therefore conservation activities have to be developed properly. Ecosystem services are produced in the social-ecological system to increase human well-being and resilience.
\end{abstract}

Keywords: Conservation, composition, diversity index, flora, species

\section{INTRODUCTION}

The ecosystem of the forest is the prominent terrestrial biodiversity bank and biological carbon pool. It controls a significant role to maintain biodiversity, provide an ecosystem, and alleviate climate change. The resilience of the ecosystem can be stated as an emergent ecosystems attribute, which is endowed by multiple levels' biodiversity (Wheeler et al. 2016; Komolafe et al. 2020; Kiat et al. 2020). Tropical forests are known as the most diverse and important terrestrial ecosystems, which serve a vital function in the global carbon cycle and being threatened by increased anthropogenic effects (Setyawan and Sugiyarto 2001; Vachnadze 2016; Komolafe et al. 2020). The tropical rainforest is the richest biological community that has the complex interaction between ecosystem services and biodiversity to human well-being-resilience (Giriraj et al. 2008; Naidu and Kumar 2016; Fedele et al. 2017; Vacek et al. 2019).

Biodiversity information facilitated information sharing and awareness, hence enhancing the protection and conservation of unique biodiversity of local action. The important factors for biodiversity are the species composition including the co-dominant and dominant tree density and the variability of any biodiversity measure (Fedele et al. 2017; Lillo et al. 2020). The ecological important value of each species was determined by the criteria of how often it occurred, the species number, and the area that was occupied in a community (Alavaisha and Mangora 2016).

The topography of Java Island is $92 \%$ of the surface area on 1,000 $\mathrm{m}$ a.s.l. They are active or in-active Volcano Mountains (van Steenis 2010). Geographically, Petungkriyono forest is located in the south of Pekalongan Regency on Dieng Mountain, Central Java. Administratively, its status is a limited production forest and a protected forest, which is managed by Forest Management Unit of State or Perhutani of East Pekalongan (DPPK 2015; Damayanti et al. 2020). The conservationist is able to engage in systematic response to the challenge of a large-scale extinction ahead by concentrating on certain areas where there is the greatest need and the payoff from safeguard measures (Myers et al. 2000).

Petungkriyono is one of the remaining forests in Central Java that has high biodiversity, including flora and fauna. Nature-based tourism has grown rapidly over the past ten years and is expected to continue its development, especially in the biodiversity hotspot (Damayanti et al. 2020). According to several studies, nature-based tourism is the fast-growing element that creates some risks and pressure on the ecosystems. By determining the recreational sustainability of plant communities, it is also necessary to take into account their ability to recover after damage (Korolkova and Miranova 2019; Kely et al. 2021). 
To prevent the Petungkriyono forest from the negative impacts of tourism, awareness about the importance of biodiversity and the need for conservation efforts need to be raised. Ecotourism activities confirm the positive effect if managers are more collaborative with research and tourism professionals to strengthen the surveillance. Encouraging botanical knowledge among the young generation has become a serious concern to maintain sustainable forests (Trimanto and Hapsari 2016; Owuor et al. 2017; Kely et al. 2021).

There is a decline of natural forest areas and botanical knowledge among young generation due to conversion to the plantation and other land uses. Sensitization outreaches must be implemented to create awareness of the imperatives of the forest to make the young generation appreciate potentials and the use of the forest (Wiryono et al. 2019; Komolafe 2020). Although the previous study extends some useful information on the current status of forests, information on the relationship between plant diversity and conservation is lacking. The study aims to analyze the diversity of plant species, composition, and structure.

\section{MATERIALS AND METHODS}

The research was conducted in Petungkriyono SubDistrict, Pekalongan District, Central Java, Indonesia, on the northwestern Dieng Plateau. The total area of the Petungkriyono Sub-District is $73.58 \mathrm{~km}^{2}$ and $73.2 \%$ (53.47 $\mathrm{km}^{2}$ ). They are covered by the forest of the state-owned enterprise of Perhutani East Pekalongan Forest Management Unit (KPH). This study is located at $7^{\circ} 08^{\prime} 30^{\prime \prime}$ S-109'44'39" E with forest elevation ranges from 750$1,500 \mathrm{~m}$ a.s.l. Based on the criteria of density and latitude, we took five villages for the study site, namely Tlogopakis, Kasimpar, Yosorejo, Kayupuring, and Tlogohendro (Figure 1).

The primary data was collected by surveying, which was by using a circular plot area of 0.04 ha. The radius size of the circle for seedling was $1.13 \mathrm{~m}$, for sapling was 2.82 $\mathrm{m}$, for poles was $5.64 \mathrm{~m}$, and for trees was $11.29 \mathrm{~m}$. There were 60 plots established and measured on the research site. Every plot had three subplots, including seedling, sapling, and poles. In each subplot, all trees with a diameter $>20 \mathrm{~cm}$ were measured and identified: diameter at breast height, species, location, and height. Each tree was numbered sequentially after being measured.

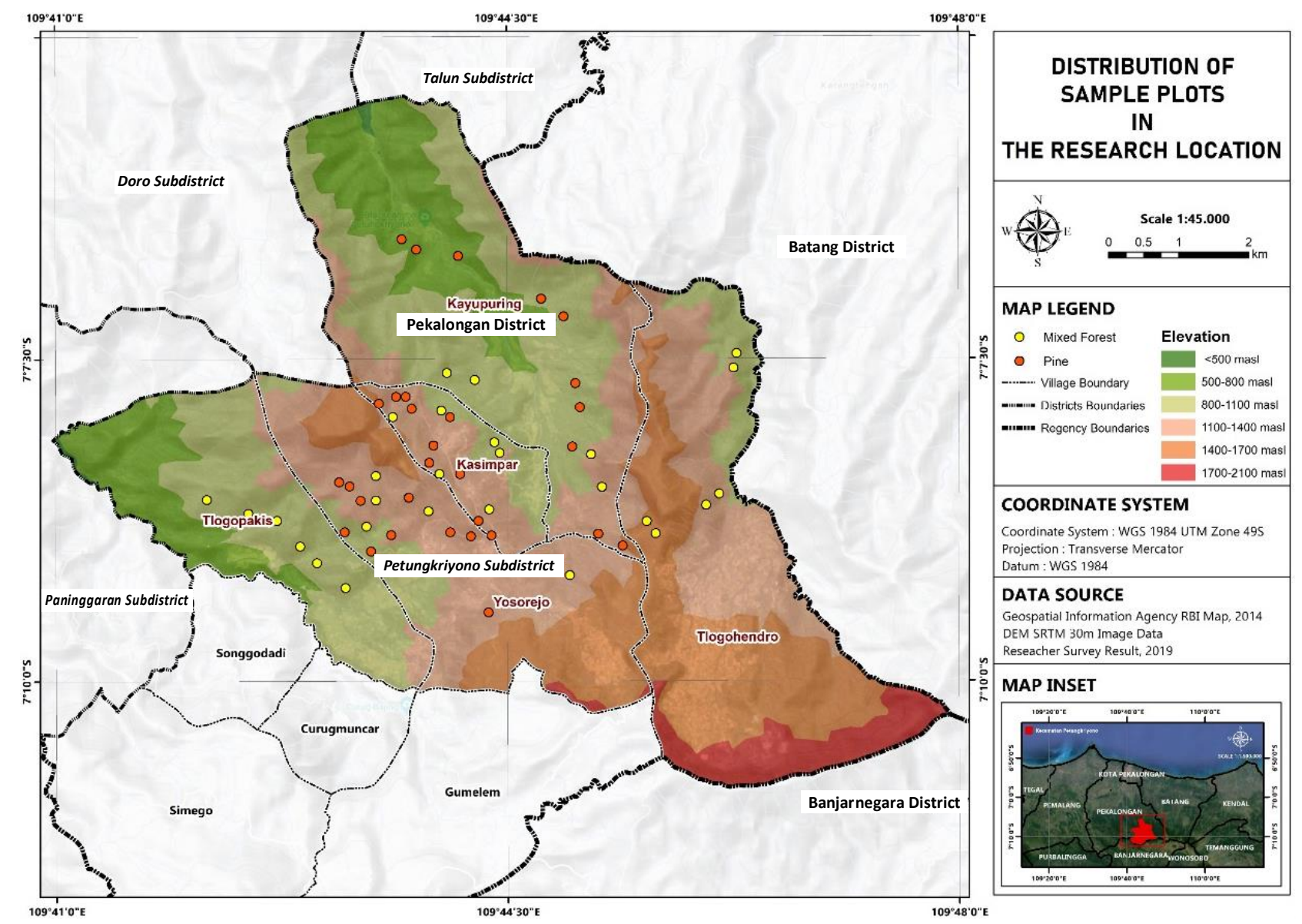

Figure 1. The distribution of sixty plots on five research sites in in Petungkriyono Sub-District, Pekalongan District, Central Java, Indonesia, on the northwestern Dieng Plateau 
Table 1. The equation of flora analysis

\begin{tabular}{|c|c|c|}
\hline About & Equation & Reference \\
\hline \multirow[t]{2}{*}{ Density } & $\mathrm{D}=\frac{\text { Total individuals of a certain species }}{\text { Vast of all sample units }}$ & $\begin{array}{l}\text { (Odum 1998; Kusumo 2016; MoEF } \\
\text { 2017; Suryana et al. 2018) }\end{array}$ \\
\hline & $\mathrm{DR}=\frac{\text { Density of a certain species } \mathrm{x} 100 \%}{\text { The density of all species }}$ & \\
\hline \multirow[t]{2}{*}{ Frequency } & $\mathrm{F}=\frac{\text { Total squares found a certain species }}{\text { Total squares }}$ & \\
\hline & $\mathrm{FR}=\frac{\text { Frequency of certain species } x 100 \%}{\text { Frequency of all species }}$ & \\
\hline \multirow[t]{2}{*}{ Dominance } & $\mathrm{D}=\frac{\text { Vast of the basic fields of a certain species }}{\text { Total vast of all sampling units }}$ & \\
\hline & DoR $=\frac{\text { Domination of a certain species x } 100 \%}{\text { Domination of all species }}$ & \\
\hline Index of Important Value (IVI) & $\mathrm{IVI}=\mathrm{FR}+\mathrm{KR}+\mathrm{DR}$ & $\begin{array}{l}\text { (Kusmana 1997; Giriraj et al. 2008; } \\
\text { Lillo et al. 2019) }\end{array}$ \\
\hline Diversity Index of Shannon-Wiener (H') & $\mathrm{H}^{\prime}=-\sum[(\mathrm{ni} / \mathrm{N}) \ln (\mathrm{ni} / \mathrm{N})]$ & \\
\hline
\end{tabular}

Note: D : Density, DR: Relative Density, F: Frequency, FR: Relative Frequency, D: Domination, DR: Relative Domination, N: Total number of individuals of the whole species in the community, ni: Number of individuals of species I found in the community, H: Species diversity, With criteria: $1<\mathrm{H}^{`}=$ Low diversity, $1<. \mathrm{H}^{\prime}<3=$ Medium diversity, $\mathrm{H}^{\prime}>3$ : High diversity

Data collection in each plot was referred to the tally sheet on the technical guidance. A handheld clinometer was used to measure the height of every individual. The next step was to identify and compare to the identification book of species in the natural forest. The various publications were used as references to identify the observed and collected plants (Odum 1998; Giriraj et al. 2008; Abedi and Pourbabaei 2010; Naidu and Kumar 2016; Kusumo 2016; MoEF 2017; Suryana 2018; Lillo et al. 2019; Amiri 2019; Addi et al. 2020; Lillo et al. 2020).

\section{Data analysis}

Data analysis was established through primary and secondary data, according to the technical guidelines of forest inventory by the Ministry of Environment and Forestry (MoEF 2017). The analysis was limited to the flora on pine forest and mixed forest based on the individual recorded. All recorded data were stored in the Microsoft Excel database and Microsoft Excel Statistics were used to analyze quantitatively. The vegetation structure is identified as girth, height class distribution, forest stand density and stands diameter (Giriraj et al. 2008; Abedi and Pourbabaei 2010; Naidu and Kumar 2016; Park et al. 2018).

The floristic structure used the Importance Value Index (IVI). It is generally calculated by summing up the relative frequency (FR), relative density (DR), and relative basal area or dominancy (DoR) of each species. The analyzed data aimed to find out the structure of flora and diversity of the flora through the biodiversity index by ShannonWiener $\left(\mathrm{H}^{\prime}\right)$. $\mathrm{H}^{\prime}$ through the Shannon diversity index computed and interpreted the diversity of plant species, since it was sensitive to forest areas like the Petungkriyono forest (Kusmana 1997; Giriraj et al. 2008; Lillo et al. 2019). The flora analysis used the formula of density, relative density, dominance (basal area), relative dominance, frequency, relative frequency, and the important value index (Table 1).

The diversity of plant species was computed and interpreted by using $\mathrm{H}^{\prime}$ through the Shannon diversity index was sensitive to forest areas like Petungkriyono forest (Kusmana 1997, Giriraj et al. 2008, Lillo et al. 2019). The measurement of this research calculated the percentage and number of influences given by a certain plant to their community. Hence, the flora analysis was done to all levels of growth by using the following formulas (Table 1).

This research used the guidelines from The Ministry of Forestry and Environment No: P.1/PKTL/IPSDH/PLA.1/ 2017 about the Technical Instructions of Forest Inventory of Protected Forest Management Unit and Production Forest Management Unit. The level of tree species life was divided into 4 as follows: (i) Seedlings: trees' rejuvenation with height $<1.5 \mathrm{~m}$, (ii) Saplings: trees' rejuvenation with height $\geq 1.5 \mathrm{~m}$ diameter at breast height $<5 \mathrm{~cm}$, (iii) Poles: trees with diameter at breast height $\geq 5 \mathrm{~cm}$ until $<20 \mathrm{~cm}$, (iv) Trees: diameter at breast height $\geq 20 \mathrm{~cm}$.

The International Union for Forestry Research Organization (IUFRO) classification scheme was used to analyze the vertical structure of the woody species. These classify story into: (i) upper, where the height of the tree/shrub is greater than $2 / 3$ of the top height; (ii) middle, where the height of the tree/shrub is in between $1 / 3$ and 2/3 of the top height; and (iii) lower, where the height of the 
tree/shrub is less than $1 / 3$ of the top height (Lamprecht 1989).

\section{RESULT AND DISCUSSION}

\section{Composition of species}

The focus during the field surveys was only on the composition of flora at pine forest and mixed forest. The five research fields had the specific characteristic of dominant species and different latitudes or contours, the analysis shows evergreen formation at elevation 700-1,500 $\mathrm{m}$ a.s.l. The composition of flora at Petungkriyono forest was dominated by mixed forest $(55 \%)$, pine forest $(29 \%)$, puspa forest $(11 \%)$, and unproductive area $(5 \%)$.

Very distinctive forest physiography has a distinctive life form as well. One of the characteristics of protected forests and production forests in Java is the composition of the species of pine Pinus merkusii and puspa Schiima wallichii (Setyawan and Sugiyarto 2001). The highest distribution of mixed forest area was founded at Kayupuring and the highest distribution of pine forest and puspa forest were founded at Tlogohendro (Figure 2).

The result shows that the composition of Sumatran Pines' species (Pinus merkusii Jungh et de Vries) has an immense standing tree potential, which is more than $95 \%$ in the limited production forest area owned by Perhutani of East Pekalongan. This study showed that the soil temperature in pine forest was $24.60^{\circ} \mathrm{C}$, relative humidity 76.6, and light intensity was 509 lux. Pine tree planting is one of Perhutani's strategies to achieve their goal's orientation in achieving profit and sustainability (DPPK 2015).

The composition of species at Petungkriyono mixed forest serves as a habitat of a variety of threatened, endemic, and unique species. These factors influence the distribution of species, including the floristic composition and structure of woody vegetation. The result revealed that the mixed forest at the research site was mostly having slope $>45 \%$ and the soil temperature was $24^{\circ} \mathrm{C}$, relative humidity was 79, and light intensity was 391.3 lux. The mixed forest at Central Java has been characterized as tropical forest type with upper Montana forest habitat and the ecological systems have the type of mosaic landscape with a land cover of $75 \%$. There is a strong correlation between site elevations and species diversity. Therefore, an area with high species diversity produces in a more stable and productive ecosystem. Most remaining high biodiversity forests are located across upland and higher elevation landscapes (Lillo et al. 2020).

The flora composition of the Petungkriyono forest is relatively more conserved due to its geographical position and its limitation. The greatest potential forest has high biodiversity and has become the last protection for the ecosystem in Central Java (DPPK 2015; Damayanti et al. 2020).

The previous study reported that Kakachi forest in India showed high species richness. The species composition was $34 \%$ of the tree and $67 \%$ of the basal area. The dominant species are Cullenia exarillata, Palaquium ellipticum, Aglaia bourdillonil, and Myristica dactyloide. To predict the floristic composition, the stand structure, and topography are used. The habitat and primary forest need to be maintained, so the core endemic species survive (Giriraj et al. 2008).

The floristic composition of the Gesha-Sayilem forest indicated that the herb layer had the highest diversity, evenness, and species richness. High plant diversity was significantly influenced by an effective environmental condition, such as altitude, slope, aspect, and especially edaphic, climate, and anthropogenic. Conservation strategies are important factors that should be considered (Addi et al. 2020).

Species composition of the mixed beech-hornbeam stand in the Shourab forest Mazandaran Province was dominated by four species. They were Oriental beach, Common hornbeam, Oak, and Caucasian alder. All of them were accounted for $90 \%$. The development stages of regeneration of all species seedlings $(50 \%)$ and saplings $(42 \%)$ have greatly increased after 10 years and very large diameter classes did not have much change over the first period. Live trees dimensions, including tree height and diameter, number, and volume of trees per hectare are different during the time. Composition and stand structure are the key attributes of a forest ecosystem (Amiri 2019).

Species composition describes the natural condition of vegetation of a certain area. As the tree species diversity is an important aspect of forest ecosystem diversity that are influenced by climate, stand structure, and geomorphology. This information about the composition of tree species helps predicting the type and abundance of the species and also the natural condition of flora. When there were different trees in a forest, the soil might be more fertile and the water might be more abundant. The forests' composition and structure were influenced by the diversity of trees' dimensions, such as tree height and diameter, number, and volume of trees per hectare (Fedele et al. 2017; Amiri 2019).

\section{Structure of forest}

The forest structure is essential to provide information on species richness, forest ecology, and ecosystem function of different types of forest habitat, including the tree height, diameter, and basal area. The vertical stratification of the forest in each habitat can be seen in the tree structure (Giriraj et al. 2008; Supriatna 2018; Lillo et al. 2019).

The result showed that pine forest and mixed forest were dominated by small size trees, ranging from $10-20 \mathrm{~cm}$ (75.98\%). Puspa forest was dominated by the number of individuals with diameters class of 21-30 cm (Figure 3). 
Table 2. Distribution of individuals with vertical analysis based on canopy cover

\begin{tabular}{|c|c|c|c|c|c|}
\hline \multirow{2}{*}{ Vertical analysis $(\%)$} & \multicolumn{5}{|c|}{ Sites } \\
\hline & Tlogopakis & Tlogohendro & Yosorejo & Kasimpar & Kayupuring \\
\hline Lower & $22.1 \%$ & $52.7 \%$ & $41.7 \%$ & $1.28 \%$ & $16.76 \%$ \\
\hline Middle & $42.4 \%$ & $25.5 \%$ & $58.3 \%$ & $39.74 \%$ & $24.32 \%$ \\
\hline Upper & $35.5 \%$ & $21.8 \%$ & 0 & $58.98 \%$ & $58.92 \%$ \\
\hline Total & 100 & 100 & 100 & 100 & 100 \\
\hline
\end{tabular}

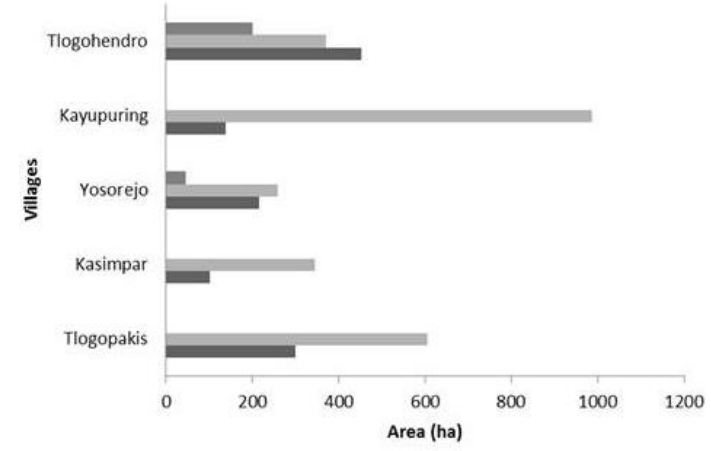

Figure 2. The composition of flora at the five research sites at Petungkriyono forest

The distribution of size-class diameter classes showed the distinction between the forest types. Generally, mixed forest and pine forest had an inverted J-shaped distribution. And it was exhibited by some tree species. Moreover, it represents a healthy regeneration (Figure 3). The species with positively skewed distribution (inverted J-curve) formed certain patterns. They commonly had the highest density in lower DBH classes with gradual declines in density towards the bigger classes. It showed good reproduction and healthy regeneration potential. The composition and density of seedling and sapling of all woody species could be used to estimate regeneration. Especially the ones, which were recorded in each sample plot.

The characteristics of the Petungkriyono forest are the distributed habitat and irregular-shaped tree species with height ranging from 5-20 m and a diameter ranging from $10-200 \mathrm{~cm}$. The various species with different age classes as primary forest $(23.5 \%)$ and secondary forest $(76 \%)$. The primary forest has had majority of the natural regeneration for over 25 years. The secondary forest has a natural regeneration stage of $0-12$ years as a young secondary forest and 12-25 years as an intermediate secondary forest with diameter ranges from $15-80 \mathrm{~cm}$.

The total number of small-sized trees in the research site was in great quantities. So, it delivered more penetration of solar energy. While the large trees might face some obstacles toward the penetration of solar radiation into the forest floor. So, the canopy became unstable and relatively short. The increasing canopy cover would increase more shade-tolerant species that have better survival. In an old-growth forest, stem density was not larger significantly than in restoration forest or young secondary forest. While the percentage cover of seedling

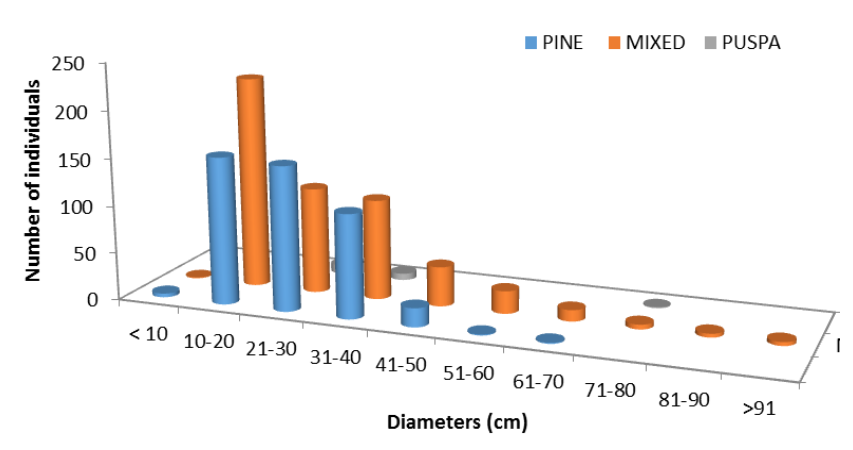

Figure 3. Distribution of size class diameter for pine forest, puspa forest and mixed forest

and canopy cover was higher than restoration forest (Wheeler et al. 2016; Vacek et al. 2019; Lillo et al. 2020; Naime et al. 2020).

The same results were reported in the mixed natural forest at the Shourab forest Mazandaran Iran, in which the highest variation in number per hectare had occurred in thin diameter classes $(15-25 \mathrm{~cm})$. The distribution of diameters at breast height of trees exhibited reverse $\mathbf{J}$ or Lshape distribution (Amiri 2019).

The previous study in Kakachi evergreen forest also indicated a healthy regeneration was caused by the majority of endemic species. They were $(82 \%)$ in the girth class $10-$ $30 \mathrm{~cm}$ (Giriraj et al. 2008). In the Dinagat Island Philippines, the number of small diameter classes was the highest in coppice forest with the higher standards values and variability (Vacek et al. 2019; Lillo et al. 2019).

Based on IUFRO classification scheme, Kasimpar and Kayupuring were classified into the upper level; Yosorejo and Tlogopakis were classified into the middle level, and Tlogohendro was in the lower level (figure 2). The top height for trees in Petungkriyono forest was $50 \mathrm{~m}$ and the average was 13.4. Kasimpar and Kayupuring had a similar dominancy of upper vegetation, which was about $58.9 \%$. The high distribution of upper-level flora shows the higher basal area and is made up mostly of trees with a higher girth and biomass. In this forest, the canopy fully closed the stand and obstructed species to grow. It caused the beginning of successional species. Tlogohendro contributed $52.7 \%$ of lower vegetation and represented in disturbing ecosystems because their poor drainage and species richness are the lowest in grassland with fewer tree species. Two villages were dominated by the middle level; Tlogopakis (42.4\%) and Yosorejo (58.3\%), it means that 
the floras are typically quite tolerant of seasonal changes and well-established ecosystems.

According to the structure of vertical flora in Table 2, the Petungkriyono forest is dominated by the number of individuals on all levels of the header's class. It showed that the vertical structure in Petungkriyono forest was dominated by tolerant types that could live and survive for a long time as the understory types. The existence of all categories proved that the succession process was running in the Petungkriyono forest (Suryana et al. 2018)

The vertical analysis was dominated by wood density, canopy cover, and understory. The previous study in Dinagat Island showed that the forest structure with an elevation ranges from $750-929 \mathrm{~m}$ is the highest peak, with vegetation cover is estimated $70-90 \%$ and canopy cover is ranging from $10-40 \%$. The result implies that plants tend to reduce their structure as an adaptation to low water-holding capacity in higher elevations (Lillo et al. 2020).

The light penetration was high. It was caused by forest disturbance and decreasing in the canopy coverage. Lower wood density species that may favor the higher light conditions were found in restoration areas while plants had better survival. The high number of small size trees in the study area signified more penetration of solar energy on the forest. Girth class frequency describes the population structure of trees in the study is in harmony with each other (Abedi and Pourbabaei 2010; Naidu and Kumar 2016; Wheeler et al. 2016; Lillo et al. 2020).

\section{Tree species diversity}

Tree species diversity is a prominent element to find out the forest ecosystems and will be a significant tool to improve the ability to maximize biodiversity conservation. By understanding the species diversity, it might lead to understanding the plant ecology and forestry. Tree species diversity in the tropical forest differs greatly from location to location; mainly due to variation in biogeography, habitat, and disturbance. Species diversity is more common to evaluate the biodiversity of the forest. The indicator species concept is commonly applied in environmental monitoring for the watershed, wildlife conservation, habitat management, and ecosystem restoration. There are three levels of biodiversity, which are genes, species, and ecosystems. Measurement of genetic diversity was referring to the variation of genes within a species (Sutrisno 2009; Naidu and Kumar 2016; Addi et al. 2020).

Research sites are covered by 979 individuals, which belong to 108 species among 88 genera and 44 families (Table 2). The dominant families are Moraceae (32.6\%), Euphorbiaceae (18.6\%), Meliaceae (18.6\%), Lauraceae $(16.2 \%)$, Rubiaceae (13.9\%), Malvaceae (11.6\%), and so on. Moraceae had the maximum number of Ficus species that are known as the key species in the tropical rain forest (Lee et al. 2013).

The result of this study found that there were more than 10 species of Ficus as a key pioneer in dry habitat, including Ficus carica, Ficus padana, Ficus benjamina, Ficus stupenda, Ficus racemosa, Ficus variegate, Ficus sinuata, Ficus lepicarpa, Ficus globosa, and Ficus toxicaria.
Euphorbiaceae had a number of species. They were classified as pioneer plant species in the early stages of secondary succession. And they carried out succession process at Petungkriyono forest. The result of the study stated that the members of Euphorbiaceae, i.e. Homalanthus populneus, and Macarangan tanarius have a similar trend with those that are found in Gesha-Sayilem forest. It is where the Euphorbiaceae represented the highest number of species that is contributed over $31.21 \%$ of the total species (Addi et al. 2020).

The value of diversity at Tesso Nilo forest is greater than the one in the Petungkriyono forest. Tesso Nilo forest has the highest diversity of vascular plants and habitats for endangered species. Furthermore, forest clearing will damage forest functions. Moreover, it will lead to the extinction of various flora and fauna species. Encroachment was degrading numerous vegetation, resulted in the change of the structure of vegetation (Kusumo et al. 2016).

The conservation status of tree species was listed according to IUCN (2020:3). It shows what actions and where they need to be done to save the building blocks of nature from extinction. It delivers a straightforward way to decide which biodiversity factor is needed to provide useful information on the species. Based on Table 3, there were eleven species from the family of Meliaceae, Fabaceae, Moraceae, Pinaceae, Theaceae, Dipterocarpaceae, Actinidaceae that were threatened and categorized as Vulnerable (VU). Dipterocarpus hasseltii, Shorea javanica, Pittosporum ferrugineum, and Castanopsis argentea were found as Endangered (EN). The forty-seven of the species were classified as Least Concerned (LC) and were still dominant in the wild. However, based on IUCN classification, we also found forty-six species that were Not Evaluated (NE). The rest of the species were Magnolia montana counted as Data Deficient (DD).

The previous study has explained tree diversity at Bawean Island Nature Reserve, East Java, Indonesia. There are about 432 plant species under 286 genera and 103 families that have been registered; comprised of 14 growth habits (with about 237 dominant species). The evaluation of conservation status shows that at least 33 species of plants were found, included the ones in the IUCN list. There are 30 species, which are categorized as Least Concern, and 3 species, which are measured at higher risk of extinction, i.e. Podocarpus rumphii (Near Threatened); Pterocarpus indicus and Memecylon myrtilloides (Vulnerable). If the Petungkriyono forest is well managed, it must have nature-based and eco-tourism similarities with the development of Bawean Island, especially to both biodiversity conservation and alleviating prosperity of the residents (Trimanto and Hapsari 2016).

This research also founded 15 species had all categories, starting from seedling, sapling, poles until becoming trees, such as Schiima wallichii, Turpinia sphaerocarpa, Syzygium sp, Nauclea obtusa, and Aglaia argentea. The high seedlings and saplings implied high regeneration, more number of seedlings, and sapling growing on the forest floor. And those categories built high species diversity (Alavaisha and Mangora 2016; Lillo et al. 2019). 
Table 3. The species categories at Red List IUCN from the research sites of the Petungkriyono forest, Central Java, Indonesia

\begin{tabular}{|c|c|c|}
\hline Species & Family & Category \\
\hline Acalypha lanceolata & Euphorbiaceae & $\mathrm{NE}$ \\
\hline Acer laurinum & Sapindaceae & $\mathrm{LC}$ \\
\hline Acronychia trifoliolata & Rutaceae & $\mathrm{LC}$ \\
\hline Actinodaphne glabra & Lauraceae & LC \\
\hline Agathis dammara & Araucariaceae & VU \\
\hline Alangium rotundifolium & Cornaceae & $\mathrm{NE}$ \\
\hline Albizia chinensis & Fabaceae & LC \\
\hline Alstonia spectabilis & Moraceae & $\mathrm{LC}$ \\
\hline Anthocephalus cadamba & Rubiaceae & $\mathrm{NE}$ \\
\hline Antiaris toxicaria & Moraceae & $\mathrm{LC}$ \\
\hline Antidesma montanus & Phyllanthaceae & $\mathrm{NE}$ \\
\hline Archidendron pauciflorum & Fabaceae. & $\mathrm{NE}$ \\
\hline Artocarpus elasticus & Moraceae & VU \\
\hline Artocarpus heterophyllus & Moraceae & $\mathrm{NE}$ \\
\hline Astronia spectabilis & Melastomataceae & $\mathrm{NE}$ \\
\hline Basella alba & Basellaceae & $\mathrm{NE}$ \\
\hline Bischofia javanica & Phyllanthaceae & $\mathrm{LC}$ \\
\hline Blumea balsamifera & Asteraceae & $\mathrm{LC}$ \\
\hline Bridelia monoica & Euphorbiaceae & $\mathrm{NE}$ \\
\hline Castanopsis acuminatissima & Fagaceae & $\mathrm{LC}$ \\
\hline Castanopsis argentea & Fagaceae & EN \\
\hline Chisocheton macrophyllus & Meliaceae & LC \\
\hline Cibotium barometz & Pteridaceae & LC \\
\hline Cinchona pubescens & Rubiaceae & $\mathrm{NE}$ \\
\hline Cinnamomum iners & Lauraceae & LC \\
\hline Cinnamomum sintoc & Lauraceae & $\mathrm{LC}$ \\
\hline Coffea canephora & Rubiaceae & $\mathrm{LC}$ \\
\hline Crypteronia peniculata & Crypteroniaceae. & $\mathrm{LC}$ \\
\hline Curculigo capritulata & Hypoxidaceae & $\mathrm{LC}$ \\
\hline Cyrtostachys lakka & Arecaceae & $\mathrm{NE}$ \\
\hline Cyrtostachys renda & Arecaceae & $\mathrm{NE}$ \\
\hline Decaspermum fruticosum & Myrtaceae. & $\mathrm{NE}$ \\
\hline Dipterocarpus gracilis & Dipterocarpaceae & VU \\
\hline Dipterocarpus hasseltii & Dipterocarpaceae & EN \\
\hline Dracantomelon dao & Anacardiaceae & $\mathrm{NE}$ \\
\hline Durio zibethinus & Malvaceae & $\mathrm{NE}$ \\
\hline Dysoxylum blumei & Meliaceae & $\mathrm{NE}$ \\
\hline Dysoxylum gaudichaudianum & Meliaceae & $\mathrm{LC}$ \\
\hline Dysoxylum nutans & Meliaceae & $\mathrm{LC}$ \\
\hline Elaeocarpus obtusa & Elaeocarpaceae & $\mathrm{NE}$ \\
\hline Elaeocarpus sphaericus & Elaeocarpaceae & $\mathrm{NE}$ \\
\hline Erioglossum rubiginosum & Euphorbiaceae & $\mathrm{NE}$ \\
\hline Erythrina lithosperma & Fabaceae & $\mathrm{NE}$ \\
\hline Eurya acuminata & Theaceae & $\mathrm{NE}$ \\
\hline Ficus benjamina & Moraceae & $\mathrm{LC}$ \\
\hline Ficus carica & Moraceae & $\mathrm{NE}$ \\
\hline Ficus globosa & Moraceae & $\mathrm{NE}$ \\
\hline Ficus lepicarpa & Moraceae & $\mathrm{LC}$ \\
\hline Ficus padana & Moraceae & $\mathrm{LC}$ \\
\hline Ficus racemose & Moraceae & LC \\
\hline Ficus sinuata & Moraceae & $\mathrm{NE}$ \\
\hline Ficus stupenda & Moraceae & $\mathrm{LC}$ \\
\hline Ficus toxicaria & Moraceae & $\mathrm{NE}$ \\
\hline Ficus variegate & Moraceae & LC \\
\hline
\end{tabular}

\begin{tabular}{|c|c|c|}
\hline Glochidion lutescens & Euphorbiaceae & $\mathrm{LC}$ \\
\hline Glochidion rubrum & Phyllanthaceae & LC \\
\hline Helicia javanica & Proteaceae & VU \\
\hline Hibiscus tiliaceus L & Malvaceae & $\mathrm{LC}$ \\
\hline Homalanthus populneus & Euphorbiaceae & $\mathrm{LC}$ \\
\hline Laportea sinuata & Urticaceae & $\mathrm{NE}$ \\
\hline Leea indica & Vitaceae & $\mathrm{LC}$ \\
\hline Lithocarpus elegans & Fagaceae. & $\mathrm{NE}$ \\
\hline Litsea angulata & Lauraceae & $\mathrm{NE}$ \\
\hline Litsea umbellata & Lauraceae & $\mathrm{LC}$ \\
\hline Macaranga tanarius & Euphorbiaceae & $\mathrm{LC}$ \\
\hline Machilus rimosa & Lauraceae & $\mathrm{NE}$ \\
\hline Macropanax dispermus & Araliaceae & $\mathrm{LC}$ \\
\hline Maesopsis emini & Rhamnaceae & $\mathrm{LC}$ \\
\hline Magnolia montana & Magnoliaceae. & $\mathrm{DD}$ \\
\hline Mallotus paniculatus & Euphorbiaceae & $\mathrm{LC}$ \\
\hline Melicope latifolia & Rutaceae & $\mathrm{NE}$ \\
\hline Melochia umbellata & Malvaceae & $\mathrm{NE}$ \\
\hline Mycromelum minutum & Rutaceae & $\mathrm{LC}$ \\
\hline Myrica javanica & Asteraceae & $\mathrm{NE}$ \\
\hline Nauclea lanceolata & Rubiaceae & $\mathrm{LC}$ \\
\hline Nauclea lanceolata & Rubiaceae & $\mathrm{LC}$ \\
\hline Neesia altissima & Malvaceae & $\mathrm{NE}$ \\
\hline Nephelium lappaceum & Sapindaceae & $\mathrm{LC}$ \\
\hline Ostodes paniculata & Euphorbiaceae & $\mathrm{NE}$ \\
\hline Palaquium rostratum & Sapotaceae & $\mathrm{NE}$ \\
\hline Pangium edule & Achariaceae & $\mathrm{LC}$ \\
\hline Pinanga javana & Arecaceae & $\mathrm{NE}$ \\
\hline Pinus merkusii & Pinaceae & VU \\
\hline Pittosporum ferrugineum & Pittosporaceae & $\mathrm{EN}$ \\
\hline Pittosporum ramiflorum & Pittosporaceae & $\mathrm{NE}$ \\
\hline Planchonia valida Blume & Lecythidaceae & $\mathrm{NE}$ \\
\hline Pometia pinnata & Sapindaceae & $\mathrm{LC}$ \\
\hline Prunus arborea & Rosaceae & $\mathrm{LC}$ \\
\hline Pterospermum javanicum & Malvaceae & $\mathrm{LC}$ \\
\hline Radermachera gigantea & Bignoniaceae & $\mathrm{LC}$ \\
\hline Sandoricum koetjape & Meliaceae & VU \\
\hline Saurauia bracteosa & Actinidaceae & VU \\
\hline Schima wallichii & Theaceae & VU \\
\hline Shorea javanica & Dipterocarpaceae & $\mathrm{EN}$ \\
\hline Sindora javanica & Fabaceae. & VU \\
\hline Sloanea sigun & Elaeocarpaceae. & $\mathrm{NE}$ \\
\hline Sterculia oblongata & Sterculiaceae & VU \\
\hline Styrax benzoin & Styraceae & $\mathrm{NE}$ \\
\hline Swietenia mahagoni & Meliaceae & VU \\
\hline Symplocos fasciculata & Phyllanthaceae & $\mathrm{NE}$ \\
\hline Syzygium densiflorum & Myrtaceae & $\mathrm{NE}$ \\
\hline Syzygium polyanthum & Myrtaceae & $\mathrm{NE}$ \\
\hline Terminalia bellirica & Combretaceae. & $\mathrm{NE}$ \\
\hline Toona sureni & Meliaceae & $\mathrm{LC}$ \\
\hline Trema orientalis & Cannabaceae & $\mathrm{LC}$ \\
\hline Trevesia sundaica & Araliaceae & $\mathrm{NE}$ \\
\hline Tridax procumbens & Asteraceae & $\mathrm{NE}$ \\
\hline Turpinia pomifera & Staphyleaceae & $\mathrm{LC}$ \\
\hline \multicolumn{3}{|c|}{$\begin{array}{l}\text { Note: EN (Endangered); LC (Least Concerned); NE (Not } \\
\text { Evaluated); VU (Vulnerable); DD (Data deficient) }\end{array}$} \\
\hline
\end{tabular}


Table 4. Density, Important value index, basal area, and diversity of the 10 most important species in five study sites

\begin{tabular}{|c|c|c|c|c|}
\hline \multirow{2}{*}{$\begin{array}{l}\text { Site } \\
\text { Kasimpar }\end{array}$} & \multicolumn{4}{|c|}{ Ecological measurements } \\
\hline & IVI (\%) & Density (Ind ha ${ }^{-1}$ ) & Basal area $\left(\mathrm{m}^{2} \mathrm{ha}^{-1}\right)$ & Shannon-Wiener Index \\
\hline Alstonia scholaris & 45.88 & 525.00 & 0.02 & 1.88 \\
\hline Albizia chinensis & 24.75 & 200.00 & 0.01 & 2.5 \\
\hline Coffea canephora & 33.03 & 125.00 & 0.12 & 2.21 \\
\hline Artocarpus elasticus & 27.88 & 100.00 & 0.09 & 2.38 \\
\hline Terminalia bellirica & 40.89 & 125.00 & 0.18 & 1.99 \\
\hline Ficus padana & 25.92 & 75.00 & 0.13 & 2.45 \\
\hline Actinodaphne glabra & 32.26 & 175.00 & 0.04 & 2.23 \\
\hline Ficus benjamina & 39.29 & 125.00 & 0.19 & 2.03 \\
\hline Symplocos fasciculata & 14.68 & 75.00 & 0.04 & 3.02 \\
\hline Ficus globosa & 15.43 & 100.00 & 0.01 & 2.97 \\
\hline \multicolumn{5}{|l|}{ Kayupuring } \\
\hline Litsea umbellata & 72.85 & 300.00 & 0.10 & 0.88 \\
\hline Ficus carica & 26.20 & 75.00 & 0.03 & 2.27 \\
\hline Bischofia javanica & 36.49 & 75.00 & 0.08 & 2.27 \\
\hline Ficus benjamina & 50.11 & 75.00 & 0.23 & 2.27 \\
\hline Ficus stupenda & 43.13 & 50.00 & 0.16 & 2.67 \\
\hline Radermachera gigantea & 25.31 & 50.00 & 0.04 & 2.67 \\
\hline Ficus variegata & 12.02 & 25.00 & 0.04 & 3.37 \\
\hline Turpinia pomifera & 7.83 & 25.00 & 0.01 & 3.37 \\
\hline Trema orientalis & 7.83 & 25.00 & 0.01 & 3.37 \\
\hline Macaranga tanarius & 18.22 & 25.00 & 0.06 & 3.37 \\
\hline \multicolumn{5}{|l|}{ Tlogopakis } \\
\hline Macaranga tanarius & 43.54 & 150.00 & 0.08 & 1.93 \\
\hline Bischofia javanica & 51.27 & 100.00 & 0.29 & 1.77 \\
\hline Sloanea sigun & 50.97 & 125.00 & 0.22 & 1.77 \\
\hline Dysoxylum blumei & 19.56 & 75.00 & 0.02 & 2.73 \\
\hline Ostodes paniculata & 26.00 & 75.00 & 0.04 & 2.45 \\
\hline Mallotus paniculatus & 15.93 & 50.00 & $0: 01$ & 2.94 \\
\hline Laportea sinuata & 11.72 & 50.00 & 0.01 & 3.24 \\
\hline Palaquium rostratum & 11.56 & 50.00 & 0.01 & 3.26 \\
\hline Mallotus paniculatus & 25.58 & 75.00 & 0.07 & 2.46 \\
\hline Dysoxylum nutans & 43.85 & 75.00 & 0.21 & 1.92 \\
\hline \multicolumn{5}{|l|}{ Tlogohendro } \\
\hline Schiima wallichii & 44.32 & 475,00 . & 0.07 & 1.91 \\
\hline Artocarpus elasticus & 38.99 & 275.00 & 0.13 & 2.04 \\
\hline Symplocos fasciculata & 17.03 & 125.00 & 0.02 & 2.87 \\
\hline Coffea canephora & 14.37 & 200.00 & 0.02 & 3.04 \\
\hline Eurya acuminata & 29.31 & 200.00 & 0.05 & 2.33 \\
\hline Bischofia javanica & 42.26 & 175.00 & 0.20 & 1.96 \\
\hline Alstonia scholaris & 25.65 & 200.00 & 0.10 & 2.46 \\
\hline Turpinia pomifera & 26.02 & 225.00 & 0.09 & 2.44 \\
\hline Actinodophne glabra & 25.97 & 125.00 & 0.07 & 2.45 \\
\hline Ficus stupenda & 36.09 & 150.00 & 0.19 & 2.12 \\
\hline \multicolumn{5}{|l|}{ Yosorejo } \\
\hline Erythrina subumbrans & 32.49 & 550.00 & 0.01 & 2.22 \\
\hline Ficus sundaica & 40.14 & 300.00 & 0.08 & 2.01 \\
\hline Litsea umbellata & 52.41 & 400.00 & 0.09 & 1.74 \\
\hline Dysoxylum gaudichaudianum & 42.77 & 275.00 & 0.08 & 1.95 \\
\hline Radermachera gigantea & 25.41 & 250.00 & 0.02 & 2.47 \\
\hline Trema orientalis & 25.79 & 250.00 & 0.02 & 2.45 \\
\hline Coffea canephora & 21.98 & 150.00 & 0.02 & 2.61 \\
\hline Nauclea lanceolata & 17.95 & 150.00 & 0.13 & 2.81 \\
\hline Ficus benjamina & 17.18 & 125.00 & 0.02 & 2.86 \\
\hline Sindora javanica & 23.09 & 175.00 & 0.02 & 2.56 \\
\hline
\end{tabular}

Flora of Petungkriyono forest is identical to the flora of neighboring countries, such as Myanmar, Vietnam, and Thailand at the family and genera level. Bischofia javanica Blume is classified as ornamental species and medical plant in Vietnam. Due to the geographical conditions of
Indochina Peninsula, they get resemblances in cultural diversity that are derived from traditional and indigenous lifestyles (Park et al. 2018).

There are two evergreen formations in the tropical forest of Western Ghats, India: high altitude at an elevation 
of 1.279-1.306 $\mathrm{m}$ with characterized by primary species and low altitude at an elevation of 1.171-1.227 m with marginal species. The primary species of Palaquium rostratum and marginal species of Macaranga tanarius had the similarity with Petungkriyono forest. The marginal species contend with primary species, especially during the successional stage. This is going to decline gradually over time (Giriraj et al. 2008).

Species richness in the natural forest of Guilan Rural Heritage Museum, Iran, was reported higher in herbaceous layer and then followed by regeneration, tree, and shrub layers. There were 75 plant species in 260 ha, containing 73 native species. And they belong to 43 families and 72 genera (Abedi and Pourbabaei 2010).

The basal area in all study sites was ranged from 0.01 $0.29 \mathrm{~m}^{2} \mathrm{ha}^{-1}$. The reported from the other study has much higher range, which is $12.98-33.63 \mathrm{~m}^{2} \mathrm{ha}^{-1}$ in the Eastern Ghats of northern Andra Prades. The basal area, density, important value index, and Shannon-Wiener index of the 10 most important species are shown in Table 4.

The differences of tree layers in the basal area were because of the different species composition, altitude, extent of disturbance, age of tree, and the successional strategies of the stands (Naidu and Kumar 2016).

The important species at Kasimpar are found in Apocynaceae family. Alstonia scholaris has the highest IVI $(45.88 \%)$, the density is 525 (individual $\mathrm{ha}^{-1}$ ) and the basal area is $1.88\left(\mathrm{~m}^{2} \mathrm{ha}^{-1}\right)$. The highest IVI at Kayupuring Litsea umbellate (72.85\%), while the density is 300 (ind ha $^{-1}$ ), and the basal area is $0.10\left(\mathrm{~m}^{2} \mathrm{ha}^{-1}\right)$. Macaranga tanarius has the highest IVI $(51.27 \%)$, the density 150 (ind $\mathrm{ha}^{-1}$ ) and the basal area $0.08\left(\mathrm{~m}^{2} \mathrm{ha}^{-1}\right)$ at Tlogopakis. Tlogohendro has the highest IVI of Schima wallichii (51.27\%), the density is 475 (ind ha $\left.{ }^{-1}\right)$, and the basal area is $0.07\left(\mathrm{~m}^{2} \mathrm{ha}^{-1}\right)$. Yosorejo has the highest IVI (52.41\%), with the density of Elaeocarpus batudulangi is 400 (ind $\mathrm{ha}^{-1}$ ) and the basal area is $0.09\left(\mathrm{~m}^{2} \mathrm{ha}^{-1}\right)$.

The highest IVI indicated that those species brought a significant to protect the stability of the ecosystem. So, it must be preserved. On the other hand, the species with lower IVI values must need higher conservation efforts. Meanwhile, those with higher IVI values must be built monitoring management. It must be acknowledged that the preservation efforts for these forests are crucial, for both the forests' rich biodiversity and the basic needs belong to the local population (Naidu and Kumar 2016).

Based on the density at five villages, which are ranged from 25-550 ind $\mathrm{ha}^{-1}$. The natural calamities, soil properties, and anthropogenic activities brought effects to the tree density (Naidu and Kumar 2016). The highest stand density found in this research was in Yosorejo villages (550 ind $\mathrm{ha}^{-1}$ ), which was Erythrina lithosperma. Whereas the lowest stand densities were in Kayupuring (25 ind $\mathrm{ha}^{-1}$ ), which were Ficus variegata, Turpinia pomifera, Trema orientalis, and Macaranga tanarius.

Tree diversity of tropical forest in Eastern Ghats of Andhra Pradesh, India, is higher than in the Petungkriyono forest. The value is less compared to those reported from India, which had a total of 2,227 individuals belonging to 129 species among 98 genera and 44 families. The highest stand density was observed in 767 individual ha ${ }^{-1}$. Whereas the lowest stand density was 435 individuals ha ${ }^{-1}$ (Naidu and Kumar 2016).

The high diversity of plants in the Petungkriyono forest is similar to Bawean Island, East Java, Indonesia. They were supported by high relative humidity, which was 79$99 \%$ with altitude up to $695 \mathrm{~m}$ a.s.1. The tree plants were dominant in 13 montane forests of Bawean Island. And they have recorded about 237 species under 144 genera and 51 families. It indicated the diversity of macro and microclimates of the forest (Trimanto and Hapsari 2016).

Comparison of this study area to Cebu Island key biodiversity areas in the Philippines showed that species richness was higher. It was because the record species were characterized into 15 families and 29 genera of the total of 50 species.

Out of 50 species, 12 indigenous species were considered as a new record. Both Petungkriyono forest and Cebu Island had higher species diversity and indigenous species (Lillo et al. 2020).

The study by Addi et al. (2020) also indicated that in Gesha-Sayilem forest, there was total of 300 plant species belong to 239 genera and 96 families. And there were only six plant families that were contributed for over $28.17 \%$ of the species total number. This is higher than the Petungriyono forest, which only has five plants families that are contributed over $10 \%$. Species diversity, altitude, and level of disturbance have strong influences on community separation.

Many studies have emphasized that tree diversity is due to topographic and physiographic conditions. Moreover, the fertility and humidity of the sites caused the high plant diversity. As the stability in an ecological system equals to high species diversity (Abedi and Pourbabaei 2010).

Biodiversity conservation and carbon emission reductions are important for managing tropical forests, which is by considering carbon stocks relative to the tree species. Biodiversity safeguards REDD+ also contains safeguards that aim to make sure its activities will not cause any negative impact to the biodiversity and environmental (social) values (Polosakan et al. 2014; Wiryono et al. 2016; Fedele et al. 2017).

One of the most impactful factors of sustainable forest management is diversity. The management plan has significantly changed at the beginning of the sampling period. While at the end of the period, the frequency of species increased. Biodiversity management is more multifarious and must deliberate the differences among various forest types, such as the forests' spatial distributions and inherent differences of species. The existing biodiversity compensation policies can be converted into Robust No Net Loss policies to close the gap (Abedi and Pourbabaei 2010; zu Ermgassen et al. 2019; Amiri 2019: Addi et al. 2020).

The loss of natural forests due to economic development reduces local botanical knowledge and biodiversity. The impact of human activities, especially agriculture, will change the whole ecosystem and biodiversity loss. Our society influenced the change indirectly and immediately. Understanding of the natural 
flora and their interaction with the surroundings has become the considerations of the stakeholders to decide the policy of natural resources utilization optimally and sustainably (Sutrisno 2009; Amiri 2019; Wiryono et al. 2019; Naidu and Kumar 2019; Komolafe et al. 2020).

In conclusion, Petungkriyono forest is biologically rich and possesses a high level of species diversity. We verified that 108 woody plant species characterized 88 genera and 43 families. Plant diversity of Petungkriyono forest plays a significant role to maintain ecosystem stability, therefore conservation activities have to be developed properly. While the forests' structural description pointed out the predominance of the small trees and shrubs. It means the Petungkriyono Forest is in the secondary regeneration stage. Appropriate attention and in-situ conservation (in their natural habitat) should be given to the species in the first and second priority classes. It can be done by doing the collaboration between local communities and other interested individuals and/ or stakeholders. The reasons for the absence of regeneration should be investigated further. Another essential task to do to save the biodiversity and ecosystem services are produced in the social-ecological system to increase human well-being and resilience. The social-ecological system by building public awareness, such as by encouraging the young generation to attend some extension programs on botanical knowledge.

\section{ACKNOWLEDGMENTS}

Our sincere gratitude goes to Perum Perhutani-KPH East Pekalongan who has supported and facilitated this research. We would like also to thank Mr. Heru Cahya Nugraha and Mr. Slamet Rahardjo for their technical guidance during fieldwork in the Petungkriyono Forest, Pekalongan District

\section{REFERENCES}

Abedi R, Pourbabaei H, 2010. Plant diversity in natural forest of Guilan Rural Heritage Museum in Iran. Biodiversitas 11 (4): 182-186. DOI: 10.13057/biodiv/d110403.

Addi A, Soromessa T, Bareke T. 2020. Plant diversity and community analysis of Gesha and Sayilem forest in Kaffa Zone, Southwestern Ethiopia. Biodiversitas 21 (7): 2878-2888. DOI: 10.13057/biodiv/d210702

Alavaisha E, Mangora MM. 2016. Carbon stocks in the small estuarine mangroves of Geza and Mtimbwani, Tanga, Tanzania. Int J For Res. DOI: $10.1155 / 2016 / 2068283$.

Amiri M. 2019. Some structural characteristics of mixed natural forest stand at the 10-years in the Hyrcanian Region: A Case study of Shourab Forest, Mazandaran Province, Iran. Biodiversitas 20 (4): 950-955 DOI: 10.13057/biodiv/d200403.

Damayanti I, Aziz NB, Soeprobowati TR. 2020. The analyzes of collaborative management perspective of Petungkriyono forest. E3S Web Conf 202, 05014. DOI: 10.1051/e3sconf/202020205014

Dinas Pertanian Perkebunan dan Kehutanan Kabupaten Pekalongan (DPPK). 2015. Identifikasi satwa dan tanaman langka /endemic untuk pelestarian sumberdaya genetic dan plasma nutfah. AFOD of Pekalongan City (in press). DOI: 10.13057/biodiv/d170261. [Indonesian]

Fedele G, Locatelli B, Djoudi H. 2017. Mechanism mediating the contribution of ecosystem services to human well-being and resilience. Ecosyst Serv 28: 43-54. DOI: 10.1016/j.ecoser.2017.09.011.

Giriraj A, Murthy M, Ramesh B. 2008. Vegetation composition, structure, and patterns of diversity: A case study from the tropical wet evergreen forests of the Western Ghats, India. Edinburgh J Bot 65 (3): 1-22. DOI: $10.1017 / \mathrm{S} 0960428608004952$

IUCN. 2020. IUCN Red List of threatened species. http://www.redlist.org Kely MR, Kouakou CY, Béné JCK, Tiedoué MR, Diarrasouba A, Tondossama A, Kuehl HS, Waltert M. 2021. Research and tourism affect positively the occupancy pattern of Loxodonta cyclotis (Elephantidae) in Taï National Park, Côte d'Ivoire. Nat Conserv Res 6 (1): 68-77. DOI: $10.24189 /$ ncr.2021.012

Kiat PE, Malek MA, Shamsudin SM. 2020. Net carbon stock change in biomass from wood removal of tropical forest in Sarawak, Malaysia. J King Saud Univ - Sci 32 (1): 1096-1099. DOI: 10.1016/j.jksus2019.09.012

Komolafe ET, Chukwuka KS, Obiakara MC, Osonubi O. 2020. Carbon Stocks and sequestration potential of Ibodi monkey forest in Atakumosa, Osun State, Nigeria. Trees, For People 2: 100031. DOI: 10.1016/j.tfp.2020.100031

Korolkova EO, Mironova AV. 2019. Recreational sustainability of bog plant communities in Polistovsky State Nature Reserve (Russia). Nat Conserv Res 4 (4): 73-80. DOI: 10.24189/ncr.2019.065

Kusmana C. 1997. Metode Survei Vegetasi. IPB, Bogor, Indonesia. [Indonesian]

Kusumo A, Bambang AN, Izzati M. 2016. Struktur vegetasi kawasan hutan alam dan hutan terdegradasi di Taman Nasional Tesso Nilo. Jurnal Ilmu Lingkungan 14 (1): 19-26. DOI: 10.14710/jil.14.1.19-26 [Indonesian]

Lamprecht H. 1989. Silviculture on The Tropics. Tropical Forest Ecosystems and Their Tree Species - Possibilities and Methods for Their Long Term Utilizations. Eschborn, GTZ, DE.

Lee SH, Ng ABC, Ong KH, O’Dempsey T, Tan HTW. 2013. The status and distribution of Ficus hispida L.f. (Moraceae) in Singapore. Nat Sing 6: 85-90.

Lillo EP, Malaki AB, Alcazar SMT, Rosales R, Redoblado BR, Pantinople E, Nueva RU, Cutiliar RC, Almirante A. 2020. Diversity and distribution of ferns in forest over limestone in Cebu Island Key Biodiversity Areas (KBAS) Phillipines. Biodiversitas 21 (1): 413421. DOI: $10.13057 /$ biodiv/d210148.

Lillo EP, Fernando ES, Lillo MJR. 2019. Plant diversity and structure of forest habitat types on Dinagat Island, Philippines. J Asia-Pac Biodivers 12 (1): 83-105. DOI: 10.1016/j.japb.2018.07.003.

Ministry of Environmental and Forestry (MoEF). 2017. Surat Keputusan Dirjen Planologi dan Tata Lingkungan No: P.1/PKTL/IPSDH/PLA.1/2017 Petunjuk Teknis Inventarisasi Hutan dan Sosial Budaya Masyarakat pada Kesatuan Pengelolaan Hutan Lindung (KPHL) dan Kesatuan Pengelolaan Hutan Produksi (KPHP). [Indonesian]

Myers NA, Mittermeier RA, Mittermeier CG, Fonseca DA, Gab KJ. 2000. Biodiversity hotspots for conservation priorities. Nature 403 (6772): 853-858. DOI: 10.1038/35002501

Naidu MT, Kumar OA. 2016. Tree diversity, stand structure and community composition of tropical forest in Eastern Ghats of Andhra Pradesh, India. J Asia-Pac Biodivers 9 (3): 328-334. DOI:10.1016/j.japb.2016.03.019

Naime J, Mora F, Sanchez-Martinez M, Arreola F, Balvanera P. 2020. Economic valuation of ecosystem services from secondary tropical forest trade-offs and implications for policymaking. For Ecol Manag 473: 118294. DOI: 10.1016/j.foreco.2020.118294.

Odum EP. 1998. Dasar-Dasar Ekologi Edisi III. Gadjah Mada University Press, Yogyakarta

Owuor AM, Icely J, Newton A, Nyunja J, Otieno P, Tuda AO, Oduor N. 2017. Mapping of ecosystem services flows in Mida Creek Kenya. Ocean Coast Manag 140: 11-21. DOI: 10.1016/j.ocecoaman.2017.02.013.

Park JH, Kang HS, Bang M, Cheng HC, Jin HY, Ahn TH, Bounithiphonh C, Phongoudome C. 2018. Floristic inventory vascular plant in Nam Ha National Biodiversity Conservation Area, Lao People's Democratic Republic. J Asia-Paci Biodivers 11 (2): 300-304. DOI:10.1016/j.japb.2018.02.005

Polosakan R, Alhamd L, Rahajoe JS. 2014. Estimasi biomasa dan karbon tersimpan pada Pinus merkusii Jungh. \& de Vriese di hutan pinus Gunung Bunder, Taman Gn. Halimun Salak. Berita Biologi 13 (2): 115-120. DOI: 10.14203/beritabiologi.v13i2.684 
Supriatna J. 2018. Konservasi Biodiversitas Teori dan Praktek di Indonesia. Yayasan Pustaka Obor Indonesia, Jakarta, Indonesia. [Indonesian]

Setyawan AD, Sugiyarto. 2001. Plants biodiversity of Jobolarangan Forest Mount Lawu: 1 Cryptogamae. Biodiversitas 2 (1): 115-122. DOI: 10.13057/biodiv/d020106.

Suryana, Iskandar JP, Partasasmita R, Irawan B. 2018. Struktur vegetasi kawasan hutan pada zona ketinggian berbeda di Kawasan Gunung Galunggung Kabupaten Tasikmalaya Jawa Barat. JIL 16 (2): 130-135. DOI: $10.14710 / \mathrm{jil} 1.16 .2 .130-135$

Sutrisno H. 2009. A comparison of biodiversity between private conservation and wildlife reserve forests in Riau by using macromoths as an indicator. Biodiversitas 10 (1): 34-39. DOI: 10.13057/biodiv/d100107.

Trimanto, Hapsari L. 2016. A Botanical survey in thirteen montane forests of Bawean Island Nature Reserve, East Java Indonesia: Flora diversity, conservation status, and bioprospecting. Biodiversitas 17 (2): 832-846. DOI: 10.13057/biodiv/d170261

Vacek S, Vacek Z, ulbrichova I, Bulusek D, Prokupkova A, Kral J, Vancura K. 2019. Biodiversity dynamics of differently managed lowland forests left to spontaneous development in Central Europe. Aust J For Sci 136 (3): 249-281.

Vachnadze GS, Tiginashvili ZT, Tsereteli GV, Aptsiauri BN, Nisnianidze QG. 2016. Carbon stock sequestered from the atmosphere by coniferous forest in Svaneti. Ann Agr Sci 14 (3): 269-272. DOI: 10.1016/j.aasci.2016.08.013.

van Steenis CGGJ. 2010. Flora Pegunungan Jawa. LIPI Press Jakarta

Wheeler CE, Omeja PA, Chapman CA, Martin Gilpin, Glipin M, Tumwesigye C, Lewis SL. 2016. Carbon sequestration and biodiversity following 18 years of active tropical forest restoration. For Ecol Manag 373: 44-55. DOI: 10.1016/j.Foreco.2016.04.025

Wiryono, Puteri VNU, Senoaji G. 2016. Plant diversity in natural forest of Guilan Rural Heritage Museum in Iran. Biodiversitas 11 (4): 182-186. DOI: 10.13057/biodiv/d1 10403

zu Ermgassen SOSE, Utamiputri P, Bennun L, Edwards S, Bull JW. 2019. The role of No Net Loss Policies in conserving biodiversity Threatened by the global infrastructure boom. One Earth 1 (3): 305315. DOI: 10.1016/j.oneear.2019.10.2019. 